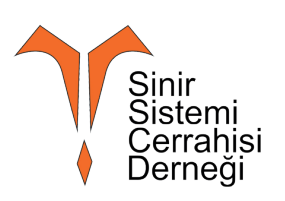

\title{
İyonize radyasyon sonrası gelişen oksidatif beyin ve spinal kord hasarını iyileştirmede deksametazon ve melatoninin etkilerinin sıçan modelinde karşılaștırılması
}

\author{
Histopathologic and biochemical \\ comparison of melatonin and \\ dexamethasone on ionizing radiation- \\ induced brain and spinal cord injuries on \\ rats
}

\author{
Emrah Egemen $^{1 \oplus}$, Özgür Öcal ${ }^{2 \oplus}$, Alp Özgün Börcek ${ }^{3 \oplus}$, Özlem Gülbahar ${ }^{4 \oplus}$, \\ Müge Akmansu ${ }^{5}$, Figen Fevziye Kaymaz ${ }^{6 \oplus}$, Ahmet Memduh Kaymaz ${ }^{3 \odot}$ \\ ${ }^{1}$ Pamukkale Üniversitesi Tıp Fakültesi, Beyin ve Sinir Cerrahisi Anabilim Dalı, Denizli. \\ ${ }^{2}$ Ankara Şehir Hastanesi, Beyin ve Sinir Cerrahisi Kliniği, Ankara. \\ ${ }^{3}$ Gazi Üniversitesi Tıp Fakültesi, Beyin ve Sinir Cerrahisi Anabilim Dalı, Ankara. \\ ${ }^{4}$ Gazi Üniversitesi Tıp Fakültesi, Tıbbi Biyokimya Anabilim Dalı, Ankara. \\ ${ }^{5}$ Gazi Üniversitesi Tıp Fakültesi, Radyasyon Onkolojisi Anabilim Dalı, Ankara. \\ ${ }^{6}$ Hacettepe Üniversitesi, Histoloji ve Embriyoloji Anabilim Dalı, Ankara.
}

Atıf/Cite as: Egemen E, Öcal Ö, Börcek AÖ, Gülbahar Ö, Akmansu M, Kaymaz FF, Kaymaz AM. İyonize radyasyon sonrası gelişen oksidatif beyin ve spinal kord hasarını iyileştirmede deksametazon ve melatoninin etkilerinin sıçan modelinde karşılaştırılması. J Nervous Sys Surgery 2021;7(3):83-95.

Geliş tarihi/Received: 26.10 .2021 Kabul tarihi/Accepted: 28.12 .2021 Yayın tarihi/Publication date: 07.01 .2022
ÖZ
Amaç: Bu çalışma sıçanlarda iyonize radyasyon sonrası gelişen beyin ve spinal kord hasarı modelinde
deksametazon ve melatonin etkinliğini karşılaşırmak için yapılmıstır.
Yöntem: Radyasyon verilen sıçanlarda tek doz 6.75 Gy (LD50) tüm vücut 1şınlaması yapıldı. Toplamda 8 adet
erkek Wistar albino sıçan rastgele olarak 4 gruba bölündü ve her bir grup 24 saatlik ve 72 saatlik takip edilecek
şekilde 2 alt gruba bölündü: 1) Sham grupları (S24 ve S72), 2) Işınlama yapılan kontrol grupları (K24 ve K72),

Sorumlu yazar/Corresponding author: Emrah Egemen, Pamukkale Üniversitesi Tıp Fakültesi, Beyin ve Sinir Cerrahisi Anabilim Dalı, Denizli. eegemen@pau.edu.tr / 0000-0003-4930-4577

Bu çalışma Gazi Üniversitesi Laboratuvar Hayvanları Yetiştirme ve Deneysel Araştırmalar Merkezi’nde (GÜDAM), Gazi Üniversitesi Deney Hayvanları Etik Kurulundan (GÜET) alınan onay sonrası (onay kodu:12,066) Dr. Emrah Egemen’in uzmanlık tezi için yapıldı.

ORCID:

Ö. Öcal 0000-0002-8985-2626, A. Ö. Börcek 0000-0002-6222-382X, Ö. Gülbahar 0000-0003-0450-4305,

M. Akmansu 0000-0002-5747-2522, F. F. Kaymaz 0000-0001-8896-2471, A. M. Kaymaz 0000-0003-2165-3273

(C) Telif hakk1 Sinir Sistemi Cerrahisi Dergisi.

Bu dergide yayınlanan bütün makaleler Creative Commons 4.0 Uluslararası Lisansı (CC-BY) ile lisanslanmıştır.

(c) Copyright Journal of Nervous System Surgery.

Licenced by Creative Commons Attribution 4.0 International (CC BY). 
3) Ișınlama sonrası deksametazon $(0,25 \mathrm{mg} / \mathrm{kg}$ ) uygulanan gruplar (D24 ve D72) ve 4) Işınlama sonrası melatonin (10 mg/kg) uygulanan grupla (M24 ve M 72). Beyin ödemi, oksidatif stres (GSH ve MDA düzeyleri ölçülerek değerlendirildi) ve histopatolojik doku hasar skoru değerlendirildi.

Bulgular: Sham grubu ile karşılaştırıldığında beyin ve sıvı içeriği kontrol gruplarında artarken deksametazon ve melatonin uygulanan gruplarda benzerlik gösteriyordu. Oksidatif stres, melatonin uygulaması ile azalmıştı. Hatta deksametazon uygulaması beyin MDA düzeylerindeki artışı ve 72 saat takip edilen spinal kord GSH düzeyindeki azalmayı engellemişti.

Sonuç: Histopatolojik inceleme, nöronal doku hasarına karșı melatoninin en az deksametazon kadar etkin olduğunu ortaya koydu. Bütün bu bulgular göstermektedir ki melatonin, iyonize radyasyona bağlı MSS hasarında koruyucu bir ajan olarak göz önüne alına bilir.

Anahtar Kelimeler: Radyoterapi, nöron hasarı, melatonin, glukokortikoid

\section{ABSTRACT}

Aim: This study was performed to compare the effects of dexamethasone and melatonin against brain and spinal cord injury due to ionizing radiation models in rats.

Methodology: Irradiated rats receive one LD50 dose (6,75 Gy) of whole-body ionizing radiation. A total of 48 male Wistar albino rats were randomized into four groups which have two different follow-up periods (24h and 72h): 1) Sham groups (S24 and S72), 2) Control groups which were irradiated (C24 and C72), 3) Dexamethasone administrated groups (0,25 mg/kg) after irradiation (D24 and D72), 4) Melatonin administrated groups (10 mg/kg) after irradiation (M24 and M 72). In addition, brain oedema, oxidative stress (evaluated by GSH and MDA assays), and histopathologic tissue damage scores were assessed.

Results: Brain water contents were higher in control groups but were similar with dexamethasone and melatonin administrated groups compared to sham groups. In addition, oxidative stress was reduced with melatonin administration. Also, dexamethasone administration prevents an increase of brain MDA in both the follow-up period and decrease of spinal GSH level in 72h follow-up period.

Conclusion: Histopathologic examination revealed that melatonin was as effective as dexamethasone to reduce neuronal tissue damage. Taking all these points into consideration suggests that melatonin can be related to protecting CNS injury induced by irradiation.

Keywords: Radiotherapy, neuronal injury, melatonin, glucocorticoid

Günümüzde, merkezi sinir sisteminin (MSS) primer ya da metastatik tümörlerinin tedavisinde radyoterapi sik olarak kullanılmaktadır. Radyoterapinin tedavi edici etkisinin yanındı bazı yan etkileri serbest oksijen radikalleri ve ROS (Reactive Oxygen Species) üretimi sonucu ortaya çıktığ 1 bildirilmiştir ${ }^{(3)}$. Bol miktarda üretilen serbest radikaller sadece lipitleri değil DNA, protein ve enzimler gibi diğer hücre biyomoleküllerinin kimyasal çatısını da yıkıma uğratmaktadır ${ }^{(19,20)}$. Bunun yanı sıra radyoterapiyi takiben antioksidan enzimlerin etkinliğinin azalması oksidatif hasarın progresyonuna katkıda bulunur ${ }^{(27)}$.

İlk yararlı etkisinin gösterildiği 1974 yılından beri glukokortikoidler radyoterapi sonras1 hem koruyucu hem de tedavi edici bir ajan olarak kullanılmaktadır. Anti-inflamatuvar, anti ödem ve immünsüpresif etkili ajanlardır, kapiller bütünlügü korur ve kollajen oluşumunu baskılarlar ${ }^{(21)}$. Ek olarak daha sonra gelişecek vasküler ve inflamatuvar değişikliklere de etkisi gösterilmiştir ${ }^{(6)}$.
Melatonin, pineal bezden sentezlenen triptofan metabolizmasının ana salg1 ürünüdür ${ }^{(25)}$. Etkin bir antioksidan ve serbest radikal temizleyici olduğu bilinmektedir. Düşük moleküler boyutu ve yüksek lipofilik bir yapıya sahip olması sayesinde biyolojik zarlardan geçer ve hücrenin bütün katmanlarına kolayca ulaşır. Bunun yanı sıra çok önemli bir antioksidan olan glutatyon (GSH)'un sentezine katkıda bulunur ${ }^{(15,20)}$. Doğrudan toksik reaktanları nötralize edip ROS üretimini inhibe ederek hücre membranlarını stabilize eder ve hücre membranını oksidatif saldırılara karşı daha dirençli hale getirir. Yüksek iyonize radyasyon durumlarında ortaya çıkan serbest radikal aracılı DNA hasarına karşı koruyucudur ve DNA hasarının onarım sürecini kolaylaştırır. Reiter ve ark, 2002 y1lında sıçanlar üzerinde yaptığ 1 bir deneysel çalışmada melatoninin aynı zamanda ciddi inflamatuvar reaksiyonları da baskılayabileceğini göstermiştir ${ }^{(16)}$.

Melatoninin nöron koruyucu etkisi birçok araştırmaya konu olmuşsa da beyin ve spinal kord üzerindeki etkisi ile ilgili araştırma 
E. Egemen et al. İyonize radyasyon sonrası gelişen oksidatif beyin ve spinal kord hasarını iyileştirmede deksametazon ve melatoninin etkilerinin sıçan modelinde karşılaştırılması

özellikle iyonize radyasyon sonrası sınırlıdır. Biz bu çalışmada iyonize radyasyonun beyin ve spinal kord dokusu üzerine yaptı̆̆ hasarının azaltılmasinda deksametazon ve melatoninin etkinliğini biyokimyasal ve histolojik olarak karşılaştırmayı hedefledik.

\section{GEREÇ VE YÖNTEM}

\section{Deney Grubu}

$\mathrm{Bu}$ çalışma Gazi Üniversitesi Laboratuvar Hayvanları Yetiştirme ve Deneysel Araştırmalar Merkezi'nde (GÜDAM) yapıldı. Gazi Üniversitesi Deney Hayvanları Etik Kurulundan (GÜET) alınan onay sonrası 4-6 aylık erkek Wistar albino sıçanlar (303-395 gr) GÜDAM'dan elde edildi.

Siçanlar 4 grup altında rastgele olarak seçildi (Tablo 1) ve her bir grup 24 saat ve 72 saat takip edildiği 2 alt grupta incelendi. Sham gruplar1 derin anestezi sonrası Kobalt (Co)-60 tedavi cihazı içerisinde diğer gruplarla aynı süre boyunca bekletildi ancak iyonize radyasyon verilmedi. Diğger gruplara derin anestezi (ketamin $\mathrm{HCl}$ ve ksilazin (im)) altında iyonize radyasyon uyguland1. Melatonin grubuna radyoterapi sonras1 birinci ve dördüncü saatlerde melatonin (SigmaAldrich $\left.^{\circledR}\right) \% 100$ etanol içerisinde çözülerek salin ile dilüe edilip (\%80 salin-\%20 etanol) $10 \mathrm{mg} /$ $\mathrm{kg}$ intra peritoneal (ip) uyguland1. Deksametazon grubuna radyoterapi sonrası birinci ve dördüncü saatlerde deksametazon (Deksamet ${ }^{\circledR}$ ) 0,25 mg / $\mathrm{kg}$ ip uygulandı. Yetmiş iki saat takip edilecek grupta aynı doz her 24 saatte bir tekrar edildi.
Sham ve kontrol gruplarına işlem sonrası birinci ve dördüncü saatlerde salin ve etanol solüsyonu aynı oranda ip uyguland 1 ve 72 saat takip edilecek gruplarda her 24 saatte bir tekrar edildi. Tüm denekler normal laboratuvar şartları altında, 18-21 ${ }^{\circ} \mathrm{C}$, on ikişer saatlik aydınlık-karanlık döngüsünde, serbest yem ve su beslemesi ile takip edildi. Deneklerin, takip sürelerinin dolmasının ardından kan ve doku örnekleri alındı.

\section{İstatistiksel Analiz}

Çalışmadan elde edilen veriler Windows SPSS 15 (Statistical Package for the Social Sciences) kullanılarak incelendi. Gruplar arasındaki farklılıkları karşılaştırmak için Kruskal-Wallis varyant testi kullanıldı. Test anlamlı olarak farklılık gösterdiğinde, farkın hangi gruplarda oluştuğunu tanımlamak üzere Mann-Whitney $\mathrm{U}$ testi uygulandi. Veriler, ortalama \pm standart sapma (SD) olarak belirtildi ve olasılık değeri $\mathrm{p}<0,05$ olduğunda istatistiksel olarak anlaml kabul edildi.

\section{Doku ve Kan Örneklerinin Alınması}

Tüm deneklerden radyoterapi öncesi biyokimyasal analiz için derin anestezi altında intrakardiyak yolla 1 cc kan alındi. Grupların tedavi ve takip süreleri tamamlandıktan sonra denekler, derin anestezi altında intrakardiyak kanları alınarak sakrifiye edildi. Alınan kanlar işlem öncesi biyokimyasal analiz için EDTA'l1 tüplere konuldu ve 3000 devirde 5 dakika santrifüj edildi. Plazma örnekleri ayrıldıktan sonra analiz dönemine kadar $-80{ }^{\circ} \mathrm{C}$ ' de sakland1.

Tablo 1. Deneysel araştırmada, deney hayvanlarının değerlendirmeye alınan grup ve alt gruplar

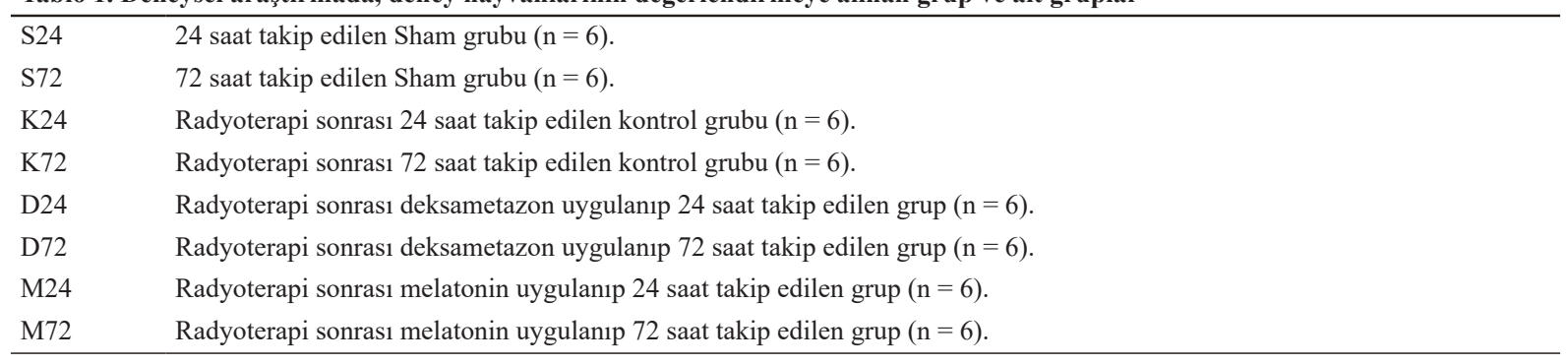


Daha sonra kraniyektomi yapıldı ve beyin dokusu çıkarıldı. Beyin dokusu üçe bölündü. Bir parça, histopatolojik inceleme için kodlanarak \%10'luk fosfat ile tamponlanmış formaldehit solüsyonuna konuldu. Diğer parça, beyin sıv1 içeriğinin ölçülmesi amaciyla hassas terazide (Precisa XB 220A) tartılıp kurutulmak üzere Eppendorf tüpüne alınd1. Son parça, alüminyum folyoya sarılıp kodlandiktan sonra s1v1 azot dolu tankın içerisine atılarak biyokimyasal analiz için incelemeye gönderildi.

Servikal total laminektomiler yapılarak spinal kord çıkarıldı. İkiye bölünerek bir parça biyokimyasal analiz için alüminyum folyoya sarılıp kodlandiktan sonra sıv1 azot dolu tankın içerisine atıldı. Doku örnekleri ayrıldıktan sonra analiz dönemine kadar- $80{ }^{\circ} \mathrm{C}$ 'de saklandı. Diğer parça da histopatolojik inceleme için beyin dokusu ile aynı formaldehit solüsyonu içerisine konuldu.

\section{Beyin Sıvı İçeriğinin Ölçülmesi}

Beyinde ödem oluşumu, denekler sakrifiye edilip beyin dokuları çıkarıldıktan sonra 1slak-kuru ağırlık yöntemiyle ölçüldü ${ }^{(18)}$. Buna göre ağırlık ölçümü alınan beyinin bir hemisferi 1slak ağırlığ ölçüldükten sonra Eppendorf tüplerine alınıp $100{ }^{\circ} \mathrm{C}$ 'de (Thermo Block TDP-120, Biosan) 24 saat boyunca kurutuldu. Daha sonra tüplerden çıkarılarak kuru ağırlıkları ölçüldü. Beyin sıv1 içeriği aşağıdaki hesaplama ile elde edildi:

Hemisferik sıvı içeriği (\%) = [(Islak ağırlık-kuru ağırlık) / Islak ağırlık] x 100

\section{Biyokimyasal Değerlendirme}

Plazma ve dokuda GSH düzeyi analizi Beyin GSH düzeyleri Ellman ve arkadaşlarının yöntemi kullanılarak analiz edildi. Bir miktar doku (yaklaşık $200 \mathrm{mg}$ ) $1 \mathrm{ml} 0.5 \mathrm{M}$ metafosforik asit ile homojenize edildi. Homojenat 3500 devirde 10 dakika santrifüj edildi ve süpernatanda GSH analizi yapıldı. GSH ölçümü için $100 \mu \mathrm{L}$ distile suya $300 \mu \mathrm{L} 1 \mathrm{M}$ potasyum fosfat tamponu (pH $=8.0$ ) eklendi. Daha sonra $2400 \mu \mathrm{L}$ DTNB eklendi ve $410 \mathrm{~nm}$ dalga boyunda absorbans1 okundu. Ardından $200 \mu \mathrm{L}$ süpernatan konularak tekrar 410 nm de okundu ve sonuçlar hesaplandı. Sonuçlar $\mu \mathrm{mol}$ GSH / gr doku olarak ifade edildi. Plazma GSH düzeyleri için süpernatan yerine serum konuldu ve aynı şekilde analiz edildi ${ }^{(5)}$.

\section{Plazma ve dokuda MDA düzeyi analizi}

Dokular 1 / 10 oranında soğuk \%1,15 KCl ile homojenize edildi. $250 \mu \mathrm{L}$ homojenat üzerine $1,5 \mathrm{ml} \% 1$ 'lik fosforik asit ve $500 \mu \mathrm{L}$ TBA eklendi. Karışım vortekslendikten sonra 45 dakika kaynar su banyosunda bekletildi. Daha sonra tüpler soğutulup $2 \mathrm{ml}$ butanol eklendi ve iyice vortekslendi. 2500 g'de 5 dakika santrifüj edildikten sonra butanol faz1 535 ve $520 \mathrm{~nm}$ dalga boylarında n-butanol karşı okundu. Absorban farkı alınarak sonuçlar nmol MDA / gr doku olarak ifade edildi (24).

Plazma MDA düzeyleri için $250 \mu \mathrm{L}$ serum üzerine $1.25 \mathrm{ml} \% 20$ 'lik TCA ve $500 \mu \mathrm{l}$ TBA eklendi. Karışım vortekslendikten sonra 30 dakika kaynar su banyosunda bekletildi. Daha sonra tüpler soğutulup $2 \mathrm{ml}$ butanol eklendi ve iyice vortekslendi. 3000 g'de 5 dakika santrifüj edildikten sonra renkli k1sım $532 \mathrm{~nm}$ dalga boyunda $n$ - butanol karşı okundu. Standartlarla oluşturulan eğri üzerinden sonuçlar hesaplandı ve nmol MDA / ml olarak ifade edildi ${ }^{(28)}$.

\section{Histopatolojik Değerlendirme}

Beyin ve spinal kord dokuları \%10'luk nötral formaldehit solüsyonunda 72 saat süreyle tespit edildi. Elde edilen parafin bloklardan $5 \mu$ kalınlığında kesitler alınarak hematoksilen-eozin (HE) ile boyandı. Kesitler mikroskop altında x 400 büyütmede incelenerek değerlendirildi. Doku hasarı değerlendirilmesi (Tablo 2), beyin ve spinal kord dokusunda nöron hücreleri, aksonal 
E. Egemen et al. İyonize radyasyon sonrası gelişen oksidatif beyin ve spinal kord hasarını iyileştirmede deksametazon ve melatoninin etkilerinin sıçan modelinde karşılaştırılması

Tablo 2. Doku hasarı değerlendirilmesinde kullanılan puanlama sistemi.

\begin{tabular}{ll}
\hline Değerlendirme Yöntemi & Puan \\
\hline Nöron & 0 \\
Normal nöron & 1 \\
Orta hasarlı nöron & 2 \\
Ağır hasarlı nöron & \\
Akson & 0 \\
Normal akson yapısı. & 1 \\
Aksonlarda orta dereceli şişme. & 2 \\
Aksonlarda ileri derecede şişme, dejenerasyon. & \\
Perivasküler alan & 0 \\
Normal damar yapısı & 1 \\
Perivasküler orta dereceli ödem & 2 \\
Perivasküler yoğun ödem & \\
\hline
\end{tabular}
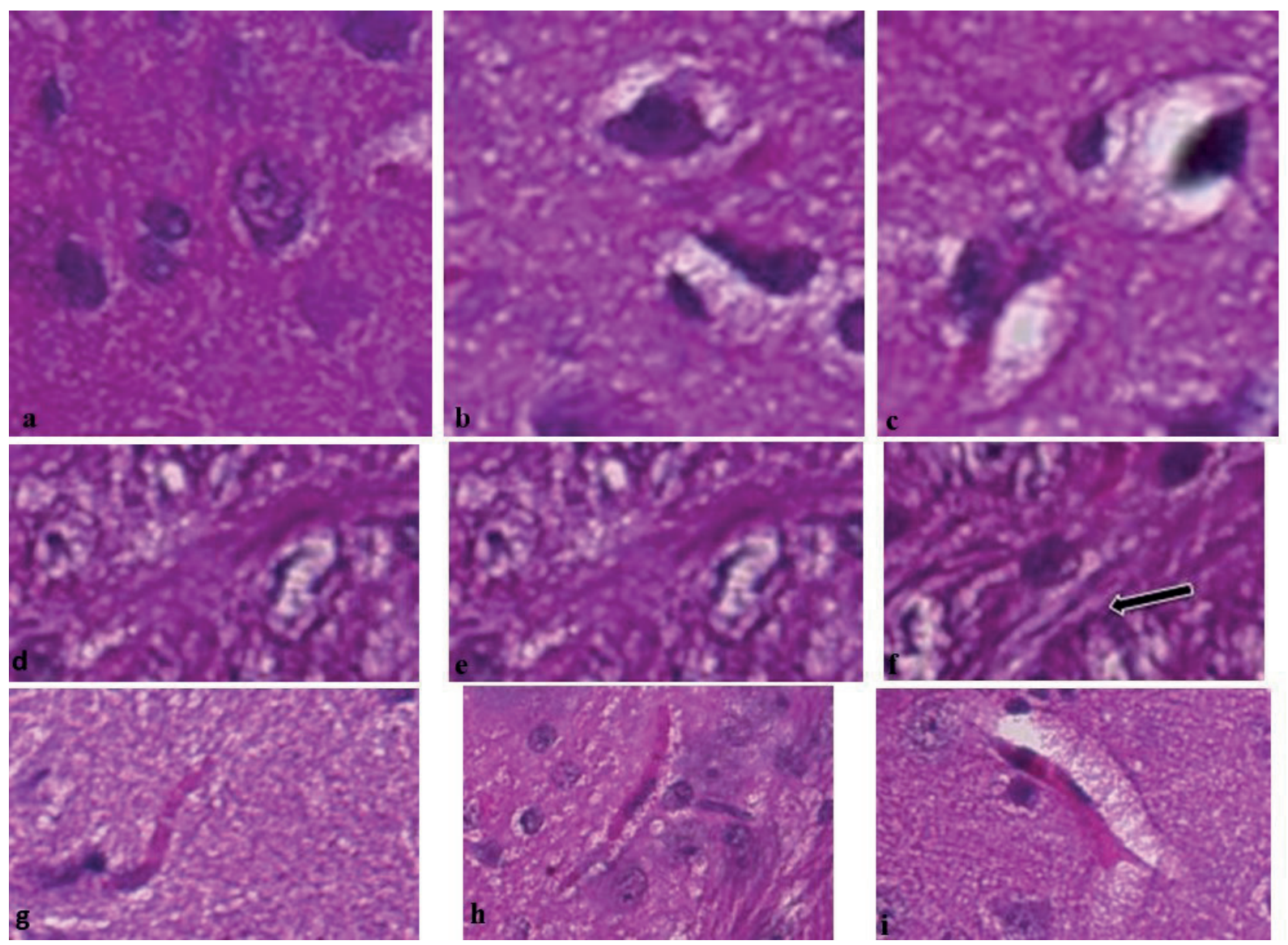

Şekil 1. Histopatolojik doku hasarı skorlaması. Normal hücre yapısına (a) 0 puan, hücre etrafı orta dereceli ödem (b) 1 puan, hücre etrafı yoğun ödem (c) 2 puan, normal akson yapısına (d) 0 puan, orta dereceli dejenerasyona (e) 1 puan ve ileri derecede dejenerasyona (f) 2 puan verildi, normal damar yapısına (g) 0 puan, perivasküler orta dereceli ödeme (h) 1 puan, yoğun ödeme (2) puan verildi. (Orijinal büyütme x400, HE)

hasar ve perivasküler ödem derecelendirilerek yapıld1 (Şekil 1). Yıldırım ve ark'ın perinöronal ve perivasküler ödem alanları, Kale ve ark'ın ise aksonal hasar derecelendirmesi modifiye edilerek bir puanlama sistemi geliştirildi ${ }^{(9,26)}$.
Her gruba ait kesitlerde rastgele olarak seçilen 20 nöron hücresi, 20 akson ve 10 perivasküler alan sayılarak 100 üzerinden doku hasarı skorlaması yap1ld1. 


\section{SONUÇLAR}

\section{Beyin Sıvı İçeriği}

Hem 24 saat hem de 72 saat takip edilen deneklerin radyoterapi verilen kontrol gruplarında Sham gruplarına göre beyin sıvı içeriğinde artış gözlendi $(\mathrm{p}=0,004)$. K24 grubu ile karşılaştırıldığında D24 $(\mathrm{p}=0,004)$ ve M24 $(\mathrm{p}=0,004)$ gruplarının beyin sıv1 içeriği anlamlı olarak daha azd1. K72 grubu ile karşılaştırıldığında D72 $(\mathrm{p}=0,006)$ ve M72 ( $\mathrm{p}=0,004)$ gruplarının beyin sıv1 içeriği anlamlı olarak daha azdı. Ancak deksametazon tedavi grubu ile melatonin tedavi grubu arasinda anlamlı farklılık yoktu (D24-M24 için $\mathrm{p}=0,200$ ve D72-M72 için p=0,109). (Şekil 2)

\section{Biyokimyasal Analiz Sonuçları}

\section{Plazma GSH ve MDA düzeyleri}

İşlem öncesi grupların homojen olduğunu değerlendirmek için Kruskal-Wallis testi uyguland1 ve gruplar arası anlamlı farkl11ık gözlenmedi $(p>0,05)$. İşlem sonrası çalışılan plazma GSH ve MDA değerlerinde ne 24 saat takip edilen deneklerde ne de 72 saat takip edilen deneklerde gruplar aras1 istatistiksel anlamlı farklılık gözlenmedi ( $p>0.05)$. İşlem öncesi ve işlem sonrası plazma GSH ve MDA düzeyleri Tablo 3 ve Tablo 4'de verilmiştir.

\section{Doku GSH düzeyleri}

Beyin GSH düzeyleri karşılaştırıldığında Kruskal-Wallis varyant testi ile hem 24 saatlik takip gruplar arasinda $(\mathrm{p}=0,02), 72$ saatlik takip gruplar arasında $(p=0,012)$ farklılık belirlendi. Her iki takip süresinde radyoterapi verilen kontrol gruplarının Sham gruplarına göre düşük düzeyi istatistiksel olarak anlamlıydı (S24-K24 için p $=0,037$ ve S72-K72 için $\mathrm{p}=0,016) . \mathrm{K} 24$ grubu ile karşılaştırıldığında D24 grubu ile anlamlı bir farkl11ık yoktu $(p=0,132)$ ancak M24 grubunun beyin GSH düzeyi anlamlı olarak daha yüksekti $(\mathrm{p}=0,010)$. K72 grubu ile karşılaştırıldığında D72 $(\mathrm{p}=0,025)$ ve M72 (p=0,030) gruplarının beyin GSH düzeyi anlamlı olarak daha yüksekti (Şekil 3). Ancak D72 grubu ile M72 grubu arasında anlamlı farklılık yoktu $(\mathrm{p}=0,262)$.

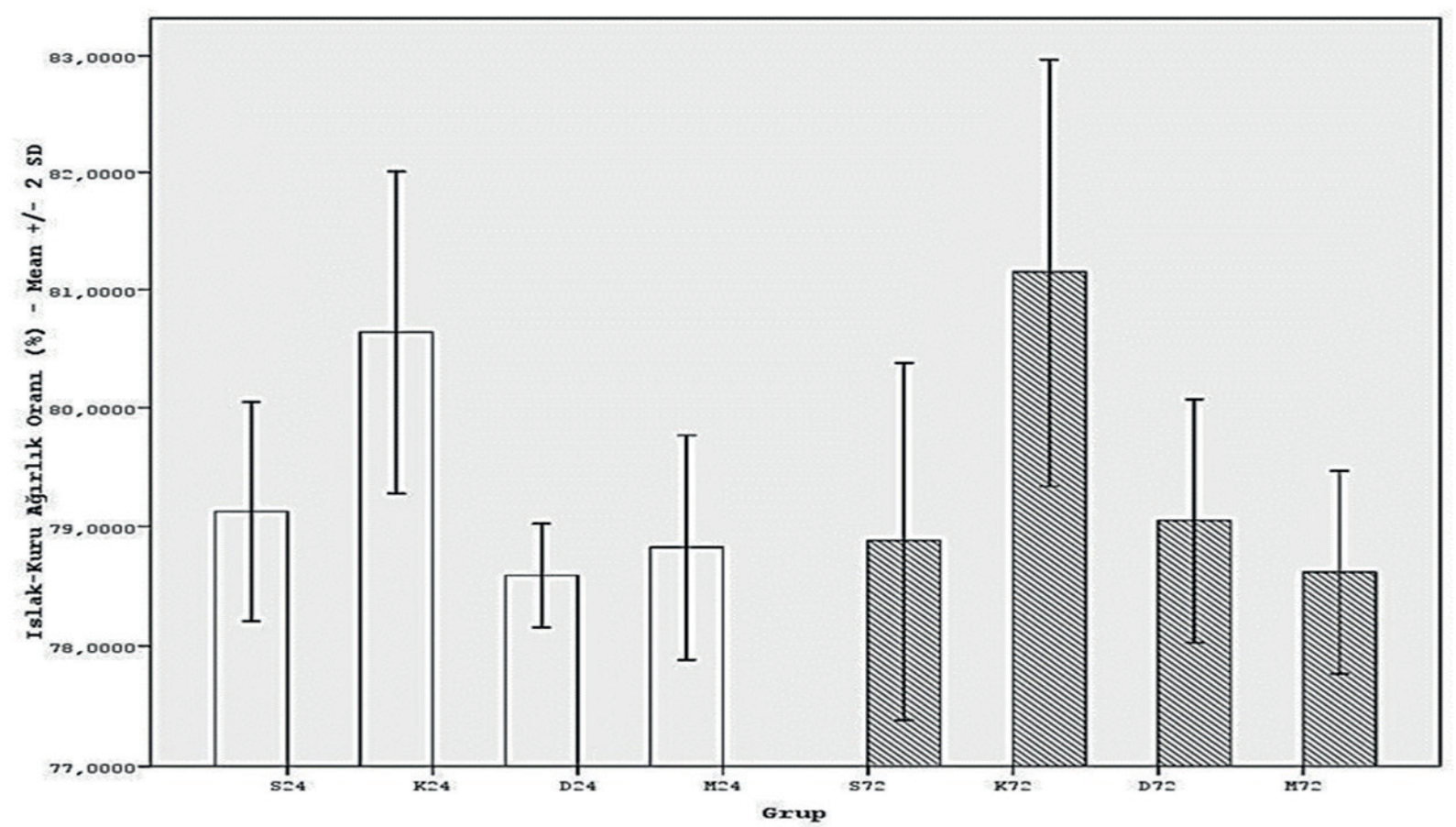

Şekil 2. Gruplara göre beyin sıvı içeriği oranları 
E. Egemen et al. İyonize radyasyon sonrası gelişen oksidatif beyin ve spinal kord hasarını iyileştirmede deksametazon ve melatoninin etkilerinin sıçan modelinde karşılaştırılması

Tablo 3. Gruplara göre plazma GSH düzeyleri

\begin{tabular}{lcccc}
\hline \multirow{2}{*}{ Grup } & \multicolumn{2}{c}{ İşlem Öncesi } & \multicolumn{2}{c}{ İşlem Sonras1 } \\
\cline { 2 - 5 } & Ortalama $(\mu \mathrm{mol} / \mathrm{ml})$ & SD & Ortalama $(\mu \mathrm{mol} / \mathrm{ml})$ & SD \\
\hline S24 & 7,1067 & 1,66333 & 1,7200 & 0,84569 \\
S72 & 6,6783 & 2,05150 & 1,5350 & 0,74506 \\
K24 & 7,5100 & 1,23008 & 1,8967 & 0,69523 \\
K72 & 5,6950 & 1,40773 & 1,9933 & 0,26934 \\
D24 & 2,10453 & 1,8767 & 0,41755 \\
D72 & 4,8940 & 2,59953 & 2,0380 & 0,53709 \\
M24 & 7,0783 & 1,40491 & 1,0700 & 0,48425 \\
M72 & 4,9175 & 1,32579 & 1,5150 & 0,30111 \\
\hline
\end{tabular}

Tablo 4. Gruplara göre plazma MDA Düzeyleri

\begin{tabular}{lcccc}
\hline \multirow{2}{*}{ Grup } & \multicolumn{2}{c}{ İslem Öncesi } & \multicolumn{2}{c}{ İslem Sonras1 } \\
\cline { 2 - 5 } & Ortalama $(\mu \mathrm{mol} / \mathrm{ml})$ & SD & Ortalama $(\mu \mathrm{mol} / \mathrm{ml})$ & SD \\
\hline S24 & 6,2333 & 0,90185 & 7,1800 & 0,69426 \\
S72 & 8,6200 & 1,72829 & 6,9500 & 0,76354 \\
K24 & 6,9500 & 1,34350 & 8,2667 & 1,39380 \\
K72 & 8,0750 & 2,51048 & 6,2333 & 0,68020 \\
D24 & 6,6200 & 1,04259 & 8,6500 & 1,21778 \\
D72 & 7,9500 & 1,48492 & 7,4000 & 1,77876 \\
M24 & 6,9333 & 0,71181 & 7,6167 & 1,33329 \\
M72 & 7,4333 & 0,52409 & 7,6833 & 1,55360 \\
\hline
\end{tabular}

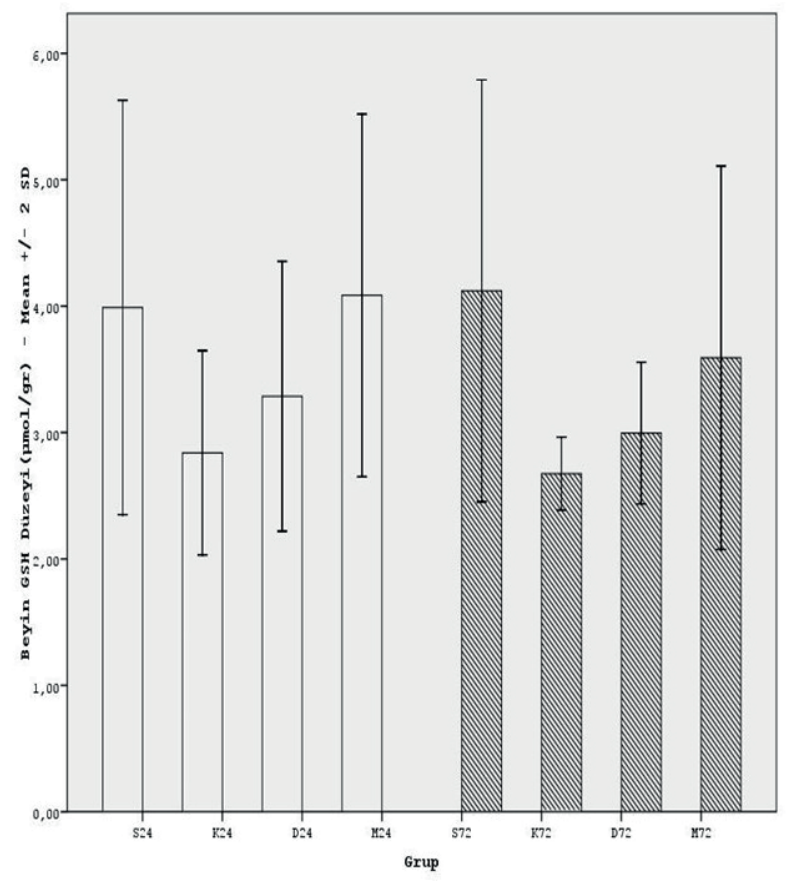

Şekil 3. Gruplara göre beyin ve spinal kordGSH düzeyleri

Spinal kord GSH düzeyleri karşılaştırıldığında Kruskal-Wallis varyant testi ile hem 24 saatlik takip gruplar arasında $(p=0,01), 72$ saatlik takip gruplar arasinda $(p=0,006)$ farkl1lı belirlendi.

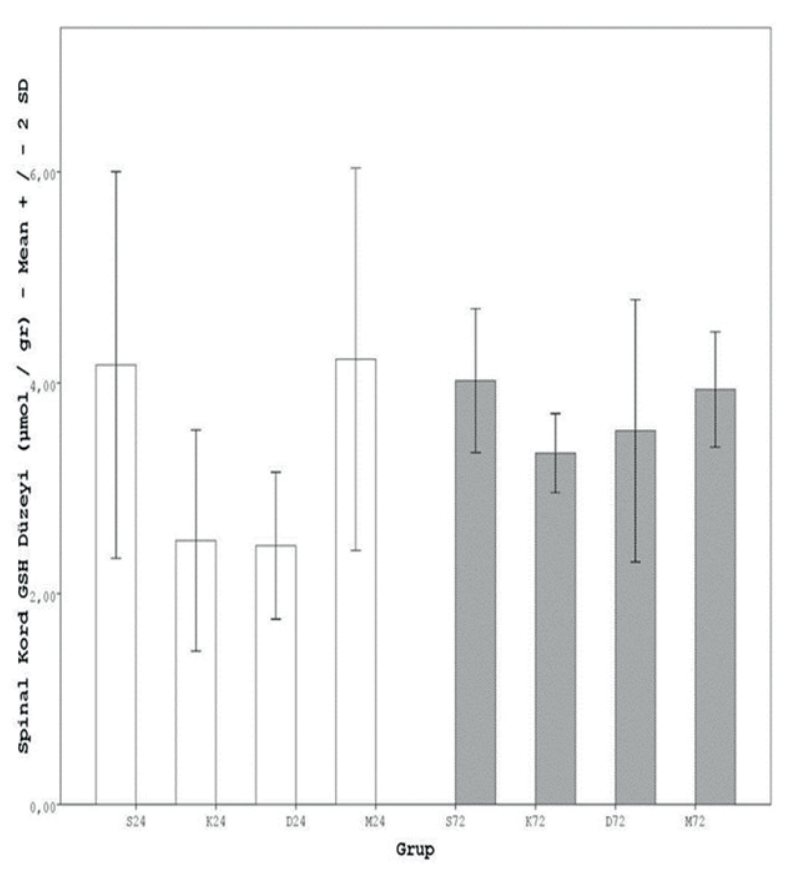

Her iki takip süresinde radyoterapi verilen kontrol gruplarının Sham gruplarına göre düşük düzeyi istatistiksel olarak anlamlıydı (S24-K24 için p $=0,04$ ve S72-K72 için $\mathrm{p}=0,006$ ). K24 grubu 
ile karşılaştırıldığında D24 grubu ile anlamlı bir farkl1l1k yoktu ( $p=1,000)$ ancak M24 grubunun beyin GSH düzeyi anlamlı olarak daha yüksekti $(\mathrm{p}=0,010)$. K72 grubu ile karşılaştırıldığında D72 grubu ile anlamlı bir farklılı yoktu ( $\mathrm{p}=$ 0,337 ) ancak M72 grubunun beyin GSH düzeyi anlamlı olarak daha yüksekti $(\mathrm{p}=0,04)$.

\section{Doku MDA düzeyleri}

Spinal kord MDA düzeyleri doku yetersizliği nedeniyle çalışılamamıştır. Beyin MDA düzeyleri karşılaştırıldığında Kruskal-Wallis varyant testi ile hem 24 saatlik takip gruplar arasında ( $\mathrm{p}=$ 0,043), 72 saatlik takip gruplar arasında ( $\mathrm{p}=$ $0,02)$ farklılık belirlendi. Her iki takip süresinde radyoterapi verilen kontrol gruplarının Sham gruplarına göre artmış düzeyi istatistiksel olarak anlamliydı (S24-K24 için p = 0,03 ve S72-K72 için $p=0,037) . K 24$ grubu ile karşılaştırıldığında D24 ( $p=0,024)$ ve M24 ( $=0,025)$ gruplarının beyin MDA düzeyi anlamlı olarak daha düşüktü (Şekil 4). Ancak D24 grubu ile M24 grubu arasında anlamlı farkl111k yoktu $(p=1,000)$ K72 grubu ile karşılaştırıldığında D72 (p=0,004) ve M72 ( $\mathrm{p}=0,037)$ gruplarının beyin MDA düzeyi anlamlı olarak daha düşüktü. Ancak D72 grubu ile M72 grubu arasında anlamlı farklılık yoktu (p $=0,335)$.

\section{Histopatolojik Doku Hasarı Skorlaması}

S24 ve S72 gruplarında beyin ve spinal kord gri cevherinde nöronlar ve aynı organların gri-beyaz cevherinde gliyal hücreleri, aksonlar ve vasküler yap1lar normal olarak izlendi. K24 ve K72 gruplarında beyin ve spinal kord dokularında gri cevherde ileri derecede nöron hasarı ile gri ve beyaz cevherde aksonlarda ileri derecede ödem ve dejenerasyon ve perivasküler alanda yoğun ödem saptand1. Her iki grubun da spinal kord hasarı daha belirgindi. D24 ve D 72 gruplarında beyin dokusunda çoğunlukla normal nöron ve aksonlar izlendi. Spinal kordda ise nöron ve aksonlardaki hasar beyin dokusuna göre daha belirgindi. Vasküler yapıların çevresinde orta derecede hasar her iki dokuda benzerdi. M24 ve M 72 gruplarında beyin dokusunda normal

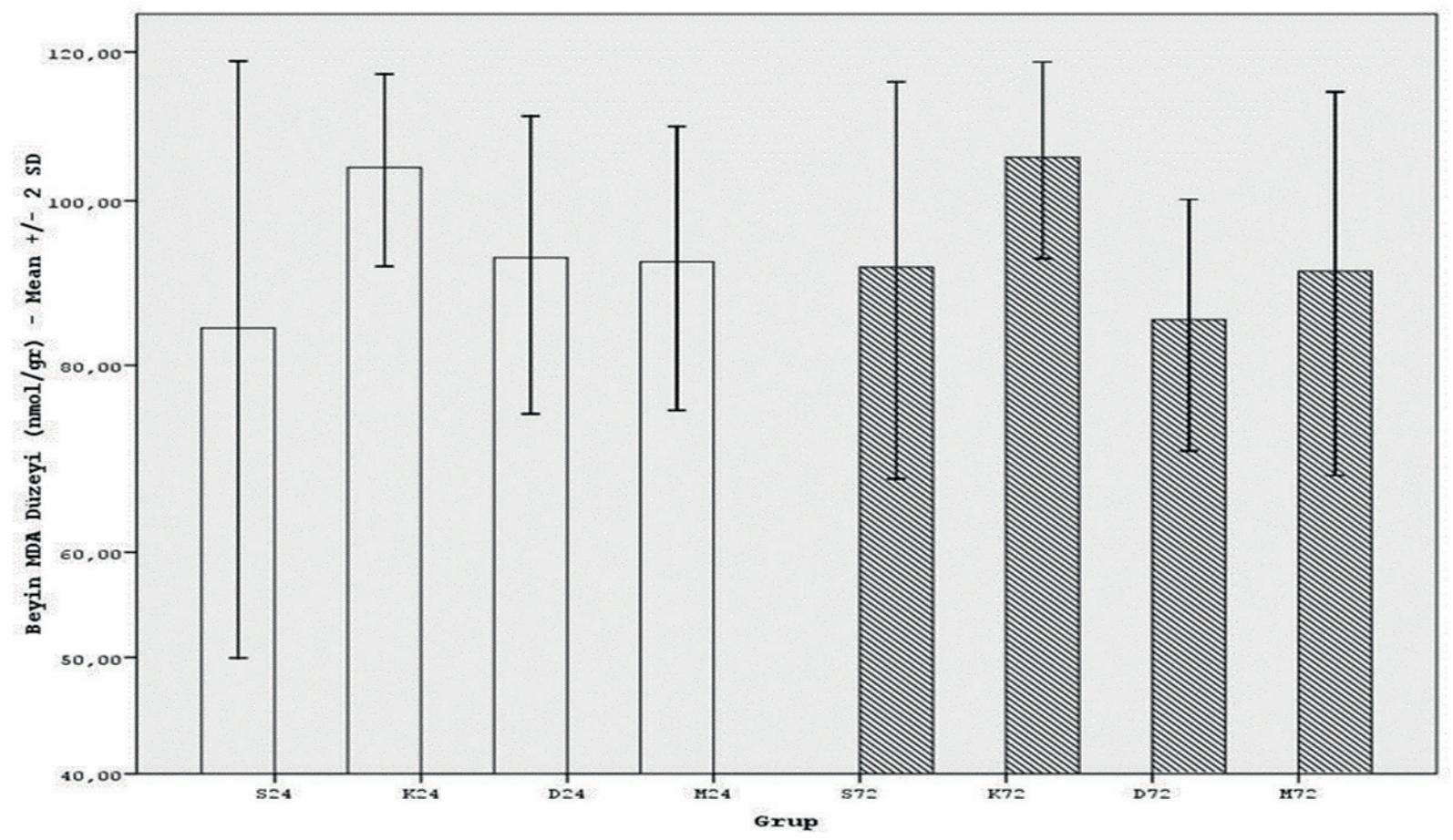

Şekil 4. Gruplara göre beyin MDA düzeyleri 
E. Egemen et al. İyonize radyasyon sonrası gelişen oksidatif beyin ve spinal kord hasarını iyileştirmede deksametazon ve melatoninin etkilerinin sıçan modelinde karşılaştırılması

ve orta derece hasarlı nöron ve aksonlar izlendi. Vasküler yapıların etrafında ödem her iki grupta da belirgindi. Spinal kordda her iki grupta da orta derecede hasarlı nöron ve aksonlar belirgindi. Vasküler yapıların etrafinda ödem her iki grupta orta düzeyde belirlendi. Hasar spinal kordda beyin dokusuna göre daha belirgindi (Şekil 5).

Beyin doku hasarı skorlaması karşılaştırıldığında Kruskal-Wallis varyant testi ile hem 24 saatlik takip gruplar arasinda $(p=0,001), 72$ saatlik takip gruplar arasında $(p=0,003)$ farklılık belirlendi. Buna göre hem 24 saat hem de 72 saat takip edilen deneklerin radyoterapi verilen kontrol gruplarında sham gruplarına göre artmış skoru istatistiksel olarak anlamlıd $1(p=0,004)$. K24 grubu ile karşılaştırıldığında D24 (p=0,006) ve M24 $(\mathrm{p}=0,006)$ gruplarının puanı daha azd1. K72 grubu ile karşılaştırıldığında D72 (p=0,004) ve M72 (p=0,008) gruplarının puanı anlamlı olarak daha azdi. Ancak deksametazon tedavi grubu ile melatonin tedavi grubu arasında anlamlı farklılık yoktu (D24-M24 için p =0,378 ve D72-M72 için $\mathrm{p}=0,631)$.

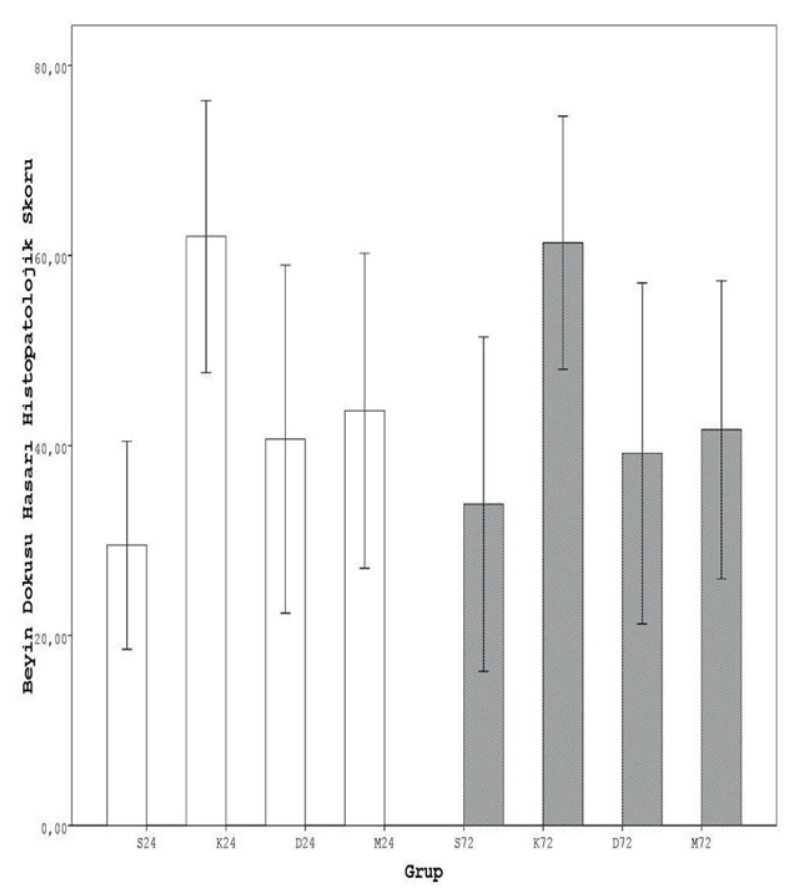

Spinal kord doku hasarı skorları karşılaştırıldığında Kruskal-Wallis varyant testi ile hem 24 saatlik takip gruplar arasında $(\mathrm{p}=0,005), 72$ saatlik takip gruplar arasında ( $p=0,004)$ farkl1lık belirlendi. Buna göre hem 24 saat $(p=0,004)$ hem de 72 saat $(p=0,006)$ takip edilen deneklerin radyoterapi verilen kontrol gruplarında sham gruplarına göre skoru artmıştı. K24 grubu ile karşılaştırıldığında D24 $(p=0,037)$ ve M24 ( $p=0,013)$ gruplarının skoru daha azdı. K72 grubu ile karşılaştırıldı ğında D72 $(p=0,006)$ ve M72 ( $p=0,016)$ gruplarının skoru anlamlı olarak daha azd1. Ancak deksametazon tedavi grubu ile melatonin tedavi grubu arasinda anlamlı farkl111k yoktu (D24-M24 için p=0,127 ve D72-M72 için $\mathrm{p}=0,127)$.

\section{TARTIŞMA}

Bu çalışmada amacımız iyonize radyasyon sonrası oluşan beyin ve spinal kord hasarında melatonin kullanımının etkinliğinin olup olmadığını saptamak ve bu etkinliği deksametazon ile karşılaştırmaktı. Bulgular göstermektedir ki,

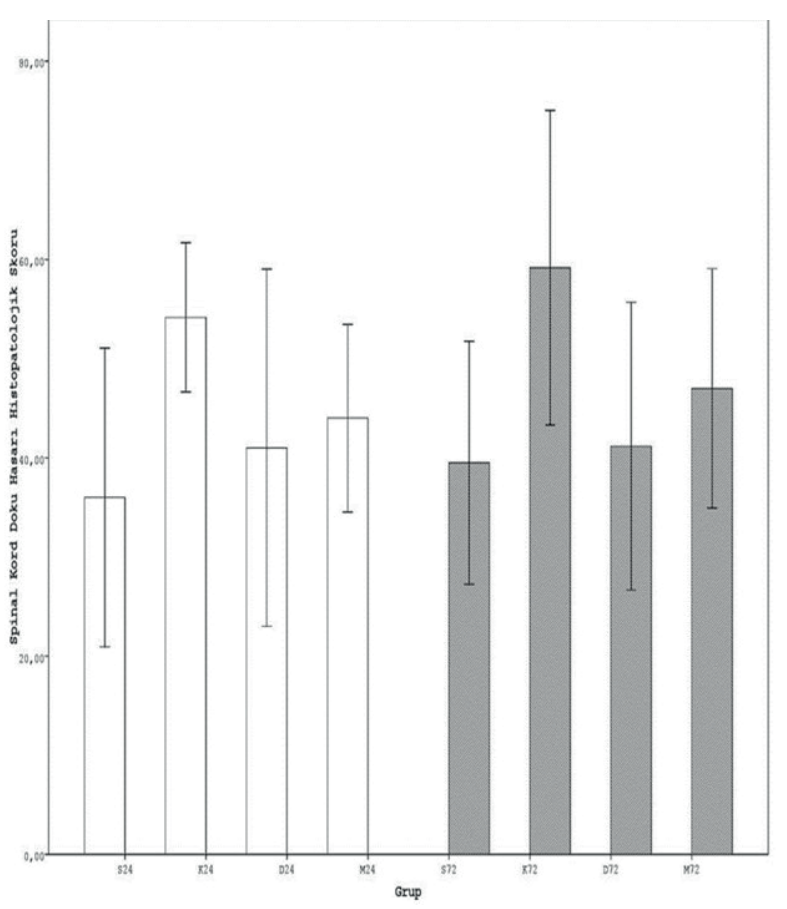

Şekil 5. Gruplara göre beyin ve spinal kord doku hasarı histopatolojik skoru 
iyonize radyasyon sonrası beyin ve spinal kord hasarında, biyokimyasal ve histopatolojik değerlendirmelere dayanarak melatonin kullanımı ile hasarın şiddeti azalmaktadır. İyonize radyasyon sonrası nöron hasarının şiddetini azaltmada melatoninin deksametazon kadar etkili olduğu ancak deksametazona üstün olmadığ1 sonucuna varılmıştır. $\mathrm{Bu}$ çalışmanın limitasyonu deney gruplarının örneklem sayısının küçük olmasıdır. Bu durum özellikle biyokimyasal değerlendirmede birbirinden farklı bulguların elde edilmesine yol açmış olabilir. $\mathrm{Bu}$ çalışmada biyokimyasal değerlendirmede, doku ve plazmada, MDA, GSH düzeylerine bakıld1. MDA oksidatif hasarın ölçülmesinde yaygın olarak kullanılan bir belirteçtir ${ }^{(9)}$. MDA düzeyinin radyoterapiyi takiben önemli ölçüde yükselmesi radyasyonun nöronlar üzerinde oksidatif hasara yol açtı̆̆ ve özellikle lipitten zengin hücre zarlarını etkilediğini ortaya koymaktadır. Bu çalışmada beyin MDA düzeyleri karşılaştırıldığında radyasyon verilen kontrol grubunda sham grubuna göre daha yüksek bulunmuştur. $\mathrm{Bu}$ durum, radyasyonun nöron üzerinde oksidatif stres yarattığını göstermektedir. Hem 24 saatlik hem de 72 saatlik takip süresinde hem deksametazon ile tedavi edilen radyoterapi grubunun hem de melatonin ile tedavi edilen radyoterapi grubunun MDA düzeylerinin kontrol grubuna göre düşüklüğü istatiksel olarak anlamlıydı. Ancak her iki tedavi grubunun da birbiri üzerinde anlamlı üstünlüğü yoktu.

Tripeptit glutatyon, bileşim yapısında tiyol içeren ve serbest radikal toksisitesine karşı savunma yapan fizyolojik bir antioksidandır. Oksijen radikallerinin temizlenmesi sirasinda meydana gelen glutatyon tüketimi hücresel glutatyon düzeyini düşürmesi nedeniyle nöronal glutatyonun azalmış düzeyi oksidatif stres için bir belirteç olarak kabul edilir. Hücre içi glutatyon düzeyi düşerken, hücre dışı glutatyon düzeyi artış gösterir ${ }^{(4,20,27)}$. Bu çalışmada plazma GSH düzeyi radyasyona maruz birakılan her iki takip süresinde de kontrol gruplarında Sham gruplarına göre daha yüksekti ve melatonin gruplarında ise kontrol gruplarına göre daha düşüktü. Ancak gruplar arası bu fark istatistiksel olarak anlamsızdı. Yildırım ve ark sıçanlar üzerinde yaptıkları benzer bir deneysel çalışmada radyasyon verilen grupta plazma GSH düzeylerinin artışı ve melatonin verilen grupta azalması istatiksel olarak anlamlı bulunmuştur.

Bununla birlikte beyin ve spinal kord GSH düzeyleri her iki takip süresinde de radyasyon verilen kontrol gruplarında sham gruplarına göre daha düşük olarak saptandı. Bu durum iyonize radyasyona bağlı oksidatif stresin oluştuğunu göstermektedir. 24 saatlik takip süresinde melatonin ile tedavi edilen grubun doku GSH düzeyleri hem kontrol hem de deksametazon ile tedavi edilen gruplara göre daha yüksekti. Bu da melatoninin, radyasyon alan diğer iki gruba göre nöronal dokuda oksidatif stresi azalttığını göstermektedir. Ancak 72 saatlik takip süresinde, deksametazon ile tedavi edilen grubun kontrol grubuna göre beyin GSH düzeyi anlamlı olarak daha yüksekti. Üstelik melatonin ile tedavi edilen gruptan anlamlı bir farkı yoktu. Hem doku GSH hem de beyin MDA düzeyleri birlikte değerlendirildiğinde deksametazonun, melatonin kadar antioksidan etkinlik gösterdiği yorumuna yol açmaktadır. Ancak böyle bir sonucun ortaya çıkması deksametazonun direkt antioksidan özelliğinden dolayı değil, antiinflamatuvar ve membran stabilize edici özelliği nedeniyle doku GSH düzeylerinin düşüşüne ve MDA düzeylerinin artışına dolaylı yoldan engel olmasıyla açıklanabilir.

Özellikle iskemik beyin hasarı, intraserebral kanama modellerinde melatoninin nöron 
E. Egemen et al. İyonize radyasyon sonrası gelişen oksidatif beyin ve spinal kord hasarını iyileştirmede deksametazon ve melatoninin etkilerinin sıçan modelinde karşılaştırılması

koruyucu etkisi gösterilmiştir ${ }^{(8,11,22)}$. Y1ldırım ve ark. iyonize radyasyon sonrası beyindeki oksidatif stresin azaltılmasinda melatonin koruyucu etkisini göstermiştir ${ }^{(26,27)}$. Yine, Lee ve ark, cerrahiye bağlı beyin hasarı modelinde düşük doz melatoninin etkinliğini gösterse de yüksek dozlarda bazı bulguların kötüleşebileceğini raporlamıştır ${ }^{(10)}$.

Literatürde deksametazonun antioksidan etkinliğine yönelik fikir birliği yoktur. Barichello ve ark, 2011 y1lında siçanlarda oluşturulan pnömokokal menenjit modelinde deksametazonun oksidatif stresi artırdığını iddia etmişlerdir ${ }^{(1)}$. Yine Mutsaers ve ark, in vitro deney modelinde deksametazonun tedavisinin oksidatif strese olan hücresel hassasiyeti artırdığını göstermiştir ${ }^{(12)}$.

Glutatyon prekürsörü amino asitlerin (glutamin, sistein) kan beyin bariyerinden geçebildiği bilinmektedir. Son y1llarda glutatyonun da kan beyin bariyerinden geçebildiğini gösteren çalışmalar yapılmıştır ${ }^{(16)}$. Dokuda çalışılan GSH ve MDA düzeyi değişikliklerinin, plazma düzeylerine istatiksel olarak anlamlı yansımaması kan-beyin bariyeri işlevinin bir sonucu olabilir. Bu biyokimyasal veriler 1şı ğında, melatonin ve deksametazonun doğrudan veya dolaylı olarak oksidatif stresi azaltan etkilerinin ortaya konması, bu tedavi ajanlarının etkinliğinin histopatolojik olarak karşılaştırılması gereğini ortaya çıkarmaktadır.

Histopatolojik veriler göstermiştir ki iyonize radyasyona bağlı MSS hasarı dakikalar içerisinde organeller düzeyinde gelişmektedir ve bunu takip eden süreçte apoptotik hücreler ve nekrotik alanlar izlenmeye başlar ${ }^{(7,19,26)}$. Öte yandan radyasyon hasarı sadece nöronlarla kısıtlı değildir, gliyal hücreler ve vasküler yatakta yer alan hücreler de etkilenmektedir. Astrosit ve vasküler endotel hücrelerinde gelişen hasarla birlikte kan beyin bariyerinin bozulması ve bu yüzden mikrovasküler geçirgenliğin artışı interstisiyel ödeme yol açacaktır ${ }^{(2,26)}$.

$\mathrm{Bu}$ çalışmanın sonuçlarına göre her iki takip süresinde de radyasyon verilen kontrol gruplarının, sham gruplarına göre beyin sıv1 içerikleri fazlayd1. Radyasyon verildikten sonra melatonin ve deksametazon ile tedavi edilen gruplarda ise yine her iki takip süresinde de beyin sıv1 içerikleri anlamlı olarak düşük bulundu. Ancak deksametazon ve melatonin tedavisi alan gruplar arasında fark yoktu. Siçanlar üzerinde yapılan iki ayrı deneysel çalışmada Rojas ve ark ile Li ve ark'1n intraserebral kanama modelinde melatoninin beyin ödemini azaltmada tek başına etkili olmadığını ortaya koymuşlardır (11,17). $\mathrm{Bu}$ çalışmada beyin ödeminin azaltılmasında melatoninin tek başına deksametazon kadar etkin olmasının nedeni verilen iyonize radyasyonun tüm beyinde etkili olması dolayısıyla hasarın daha yaygın görülmesinden kaynaklanabilir. Böylece uygulanan tedavinin etkinliğinin daha net olarak ortaya konabilmektedir. Rojas ve ark ile Li ve ark'ın sıçan modelinde hematom, beyinin sadece belirli bir bölgesinde oluşturulduğu için oluşan ödemde lezyon etrafında sınırlı kalmış ve bu yüzden melatonin beyin ödemini azaltmada etkinliği ortaya konamamış olabilir. Yine bu çalışmada, intraserebral kanama modelinden farklı olarak iyonize radyasyona bağlı gelişen nöron hasarında birincil olarak oksidatif stresin sorumlu olması, bir antioksidan olan melatonin etkinliğini daha net olarak ortaya koymuştur.

Hem beyin hem de spinal kord için her iki takip süresinde de radyasyon verilen kontrol gruplarının histopatolojik doku hasarı sham gruplarına göre daha fazlaydi. Deksametazon ve melatonin tedavisi uygulanan gruplarda ise bu skorun artışı daha azdı. Ancak tedavi grupları arasında birbirlerine karşı istatiksel olarak anlamlı bir üstünlük saptanmadı. 
Presman ve ark, 2006 yılinda fare timositleri üzerinde yaptıkları deneysel bir çalışmada melatoninin glukokortikoid reseptörlerinin birleşme eğilimini azaltabileceğini ve glukortikoidlere duyarlılığı artırabileceğini göstermiştir ${ }^{(14)}$. Bu yüzden bu iki tedavi ajanının birlikte uygulanmas1, gereken glukokortikoid dozu ihtiyacinı ve beraberinde istenmeyen yan etkilerini de azaltabilecektir. Ayrıca melatoninin deksametazon ile birlikte kullanımı antiapopitotik yolakların güçlendirilmesine ve proapopitotik yolakların ise etkinliğini azaltılmasına katkıda bulunabileceği önerilmiştir ${ }^{(11)}$.

Sonuç olarak beyin ve spinal korda iyonize radyasyon sonrası oluşan hasarı önlemede melatonin etkin bir ajandır ve bu etkinliği dexametazonla eşdeğerdir. Ancak iki tedavi ajanının birlikte kullanıldığı, denek sayısının arttırıldı̆̆ı daha geniş çalışmalara ihtiyaç vardır.

Çıkar çatışması: Çalışmamızda herhangi bir çıkar çatışması bulunmamaktadır.

Finansal destek: Çalışmamızda finansal destek alınmamıştır.

Conflict of interest: There is no conflict of interest in our study.

Funding: No financial support was received in our study.

\section{KAYNAKÇA}

1. Barichello T, Santos AL, Silvestre C, Generoso JS, Cipriano AL, Petronilho F, Dal-Pizzol F, Comim CM, Quevedo J, Dexamethasone treatment reverses cognitive impairment but increases brain oxidative stress in rats submitted to pneumococcal meningitis, Oxid Med Cell Longev, 2011, 2011:173035. https://doi. org/10.1155/2011/173035

2. Belka C, Budach W, Kortmann RD, Bamberg M. Radiation-induced CNS Toxicity-molecular and cellular mechanisms. Br J Cancer 2001; 85 (9): 1233-9. https:// doi.org/10.1054/bjoc.2001.2100
3. Davies AN, Broadley K, Beighton D. Xerostomia in patients with advanced cancer. J Pain Symptom Manage. 2001; 22: 820- 25. https://doi.org/10.1016/S08853924(01)00318-9

4. Dringen R. Metabolism and functions of glutathione in brain. Prog Neurobiol 2000; 62(6): 649-71. https://doi. org/10.1016/S0301-0082(99)00060-X

5. Ellman GL. Tissue sulfhydryl groups. Arch Biochem Biophys 1959; 82 (1): 70-7. https://doi.org/10.1016/00039861(59)90090-6

6. Genç M, Ergun U, Selek U. Radyoterapi Sonrası Beyin Hasarı ve Tedavi Yaklaşımları. UHOD 2006; 2 (16), 114124.

7. Hall EJ, Amato GJ. Radiobiology for the Radiologist, 7th ed. Philadelphia: Lippincott, Williams \& Wilkins, 2012; 130-131.

8. Hardeland R. Antioxidative protection by melatonin: multiplicity of mechanisms from radical detoxification to radical avoidance. Endocrine 2005; 27 (2): 119-30. https://doi.org/10.1385/ENDO:27:2:119

9. Kale A, Börcek AÖ, Emmez H, Yıldırım Z, Durdağ E, Lortlar N, et al. Neuroprotective effects of gabapentin on spinal cord ischemia-reperfusion injury in rabbits. J Neurosurg Spine. 2011; 15 (3): 228-37. https://doi. org/10.3171/2011.4.SPINE10583

10.Lee S, Jadhav V, Ayer RE, Rojas H, Hyong A, Lekic T et al. Dual effects of melatonin on oxidative stress after surgical brain injury in rats. J Pineal Res 2009; 46 (1): 43-8. https://doi.org/10.1111/j.1600-079X.2008.00607.x

11.Li ZQ, Liang GB, Xue YX, Liu YH. Effects of combination treatment of dexamethasone and melatonin on brain injury in intracerebral hemorrhage model in rats. Brain Res. 2009; 1264: 98-103. https://doi.org/10.1016/j. brainres.2009.01.055

12.Mutsaers HA, Tofighi R. Dexamethasone enhances oxidative stress-induced cell death in murine neural stem cells Neurotox Res 2012; 22 (2): 127-37. https://doi. org/10.1007/s12640-012-9308-9

13.Olteanu D, Filip A, Mureşan A, Nagy A, Tabaran F, Moldovan R, et al. The effects of chitosan and low dose dexamethasone on extrahepatic cholestasis after bile duct ligation in Wistar rats. Acta Physiol Hung. 2012; 99 (1): 61 -73. https://doi.org/10.1556/APhysiol.99.2012.1.7

14.Presman DM, Hoijman E, Ceballos NR, Galigniana MD, Pecci A. Melatonin inhibits glucocorticoid receptor nuclear translocation in mouse thymocytes. Endocrinology 2006; 147 (11): 5452-9. https://doi. org/10.1210/en.2006-0252

15.Reiter RJ, Tan DX, Osuna C, Gitto E. Actions of melatonin in the reduction of oxidative stress. A review. $\mathrm{J}$ Biomed Sci 2000; 7 (6): 444-58. https://doi.org/10.1007/ BF02253360

16.Reiter RJ, Tan DX, Burkhardt S. Reactive oxygen and nitrogen species and cellular and organismal decline: amelioration with melatonin. Mech Ageing Dev 2002; 123 (8): 1007-19. https://doi.org/10.1016/S00476374(01)00384-0 
E. Egemen et al. İyonize radyasyon sonrası gelişen oksidatif beyin ve spinal kord hasarını iyileştirmede deksametazon ve melatoninin etkilerinin sıçan modelinde karşılaştırılması

17.Rojas H, Lekic T, Chen W, Jadhav V, Titova E, Mart'in $\mathrm{RD}$, et al. The antioxidant effects of melatonin after intracerebral hemorrhage in rats. Acta Neurochir Suppl. 2008; 105: 19-21. https://doi.org/10.1007/978-3-21109469-3_4

18.Snyder JS, Kee N, Wojtowicz JM. Effects of adult neurogenesis on synaptic plasticity in the rat dentate gyrus. J Neurophysiol. 2001; 85, 2423-2431. https://doi. org/10.1152/jn.2001.85.6.2423

19. Somosy Z. Radiation response of cell organelles. Micron 2000; 31 (2): 165-81. https://doi.org/10.1016/S09684328(99)00083-9

20.Şener G, Jahovic N, Tosun O, Atasoy BM, Yeğen BC. Melatonin ameliorates ionizing radiation-induced oxidative organ damage in rats. Life Sci 2003; 74 (5): 563-72. https://doi.org/10.1016/j.lfs.2003.05.011

21.Tada E, Matsumoto K, Kinoshita K, Furuta T, Ohmoto T. The protective effect of dexamethasone against radiation damage induced by interstitial irradiation in normal monkey brain. Neurosurgery 1997; 41 (1): 20917. https://doi.org/10.1097/00006123-199707000-00033

22.Tomas-Zapico C, Coto-Montes A. A proposed mechanism to explain the stimulatory effect of melatonin on antioxidative enzymes. J Pineal Res 2005; 39 (2): 99104. https://doi.org/10.1111/j.1600-079X.2005.00248.x

23.Turgay M, Turgay F, Devrim E, Küçükşahin O, Çaydere M, Durak I. The effects of dexamethasone on oxidant/ antioxidant status in kidneys of rats administered mercuric chloride. Bratisl Lek Listy. 2012; 113 (1): 10-3. https://doi.org/10.4149/BLL_2012_002
24.Uchiyama M, Mihara M. Determination of malonaldehyde precursor in tissues by thiobarbituric acid test. Ann Rev Biochem 1978; 86: 271-278. https://doi. org/10.1016/0003-2697(78)90342-1

25.Vijayalaxmi, Reiter RJ, Tan DX, Herman TS, Thomas CR Jr. Melatonin as a radioprotective agent: a review. Int J Radiat Oncol Biol Phys 2004; 59 (3): 639-53. https:// doi.org/10.1016/j.ijrobp.2004.02.006

26. Yıldırım O, Çomoğlu S, Yardımcı S, Akmansu M, Bozkurt G, Avunduk MC. Melatonin treatment for prevention of oxidative stress: involving histopathologic changes. Gen Physiol Biophys 2007; 26 (2): 126-32.

27.Yıldırım Ö, Çomoğlu S, Yardımeı S, Akmansu M, Bozkurt G, Avunduk MC. Preserving effects of melatonin on the levels of glutathione and malondialdehyde in rats exposed to irradiation. Gen Physiol Biophys 2008; 27 (1): 32-7.

28. Yoshioka T, Kawada K, Shimada T, Mori M. Lipid peroxidation in maternal and cord blood and protective mechanisms against oxygen toxicity in the blood. Am J Obstet Gynecol 1979; 135: 372-376. https://doi. org/10.1016/0002-9378(79)90708-7. 